\title{
Is international tourism responsible for the outbreak of the COVID-19 pandemic? A cross-country analysis with a special focus on small islands
}

\author{
Jean-François Hoarau ${ }^{1}$ iD
}

Accepted: 31 August 2021 / Published online: 22 September 2021

(C) Kiel Institute 2021

\begin{abstract}
This article aims at analysing the role of international tourism attractiveness as a potential factor for the outbreak and the early spread of the recent COVID-19 disease across the world (also called the first wave) with a special focus on small Island economies. Econometric testing is implemented over a cross-country sample including 205 countries/territories (with 59 small islands) after controlling for several usual suspects. The results state a positive and significant relationship between COVID-19 prevalence and inbound tourism arrivals per capita. Thus in the early stages of the spread (before travel restrictions), international tourism could be seen as one of the main responsible factors for the recent pandemic, validating the "tourism-led vulnerability hypothesis". Accordingly, considering that such health shocks should be more frequent in the near future, this finding suggests that the tourism specialization model in the context of small islands is too vulnerable to be considered as sustainable in the medium and long-run. Policymakers must opt for economic diversification when possible. Otherwise, building up a strong public-health system alongside a specialized tourism sector is required.
\end{abstract}

Keywords COVID-19 · Health epidemics · International tourism · Small islands · Vulnerability

JEL Classification C31 $\cdot$ I15 $\cdot 050 \cdot$ Z32 $\cdot$ Vulnerability

Jean-François Hoarau

jfhoarau@univ-reunion.fr

1 CEMOI, TEPP, University of La Reunion, Saint-Denis, La Reunion, France 


\section{Introduction}

Since the first official case of COVID-19 reported by the Chinese authorities in midDecember 2019, what was initially a Chinese problem became rapidly an international concern. Only three months were sufficient to transform a local epidemic into an unprecedented pandemic affecting now more than 190 economies around the world (WHO, 2020). Even if it is too soon to have a clear idea about the economic consequences, the first assessments suggest that this health crisis and the associated measures to limit its spread would damage dramatically almost all countries. In a recent note, OECD (2020) argues that "the initial direct impact of the shutdowns could be a decline in the level of output of between one-fifth to one-quarter in many economies with consumers' expenditure potentially dropping by around one-third. Changes of this magnitude would far outweigh anything experienced during the global financial crisis in 2008-2009." Unsurprisingly tourism will be one of the most impacted sectors. WTO (2020b) has already estimated a loss of us $\$ 910$ billion to us $\$ 1.2$ trillion in export revenues for world tourism (850 million to 1.1 billion fewer international tourist arrivals). More generally, the earlier literature demonstrated that infectious disease outbreaks (SRAS in 2003, Chikungunya in 2005, MERS in 2012, Ebola virus in 2014 or different events of influenza) caused a strong and immediate drop in the tourism frequentation for the affected countries, even if the effect appeared often transitory (Novelli et al., 2018; Peeri et al., 2020; Siu \& Wong, 2004). Very recent economic works relative to the COVID-19 go in the same direction, but the adverse impacts both on the supply and demand sides would be undoubtedly deeper and longer (Peeri et al., 2020; Yang et al., 2020).

However, very few works have studied the reverse link that is the impact of tourism attractiveness of a destination on infectious disease outbreaks. International tourism is obviously a victim of infectious epidemics but it is also a major usual suspect for health epidemic spread. Scholars in epidemiological and medicine studies shed light on the potential for dramatically rapid dissemination of virus throughout the world as the world continues to experience expanding global trade markets and increasing international travel (Smolinski et al., 2003; Baker \& Mc, 2005). In particular, infections carried by humans and transmitted from person to person are especially likely to move from one region to another. A virus such as the COVID19, which can colonize without causing symptoms or can be transmissible at a time when infection is asymptomatic, spread easily in the absence of recognized infection in traveling hosts. Then, assuming that the contemporaneous transportation networks give the opportunity to go around the world in less than $36 \mathrm{~h}$, international tourism flows could transform local epidemics to global pandemics (Hufnagel et al., 2004). That is the reason why the WHO usually gives the recommendation to close prematurely many borders and discourages tourism in the affected areas. ${ }^{2}$

\footnotetext{
1 It is similar to a decrease of about 2-3\% in annual GDPs for each month of confinement.

${ }^{2}$ Hufnagel et al. (2004) claimed that simulations strongly support the strategy of travel restrictions, especially isolation of largest cities, as a necessary requirement for controlling highly contagious epidemics.
} 
At our knowledge, no article in the field of economics has studied this relationship at date. The aim of this paper is to fill this gap by giving some possible answers to several unsolved but fundamental questions in the context of the COVID-19 crisis. Why is the Northern hemisphere strongly more impacted than the Southern one? Why do the least developed countries seem to be relatively preserved in spite of bad health conditions? Is there any role for international tourism flows before the global process of travel restrictions? To this regard, we estimate a multiple linear regression ${ }^{3}$ between the domestic magnitude of the epidemic in the early stages of the spread, also called the first wave (before the generalized lockdowns in the third week of March), i.e. the prevalence of COVID-19 (per capita), and the destinations' tourism attractiveness, i.e. international tourism arrivals per capita, after controlling for several usual suspects (the share of elderly population, urban population rate, climate, population density, the Eastern Asian specificity) over a worldwide crosssection sample (205 countries/territories including 59 small islands). ${ }^{4}$ Our simulations finally highlight a significantly strong and positive influence of international tourism on the COVID-19 infections.

Precise that we make a special focus on small island economies for which the contribution of tourism to economic output generally exceeds that in other regions of the world (Pratt, 2015; Cannonier and Galloway 2018). For a long time, tourism specialization was the cornerstone of most small islands' development strategy in accordance with the conventional recommendation of the orthodox literature based on the so-called "tourism-led growth hypothesis" (Brau et al., 2011; Brida et al., 2016). In other words, tourism specialization was considered as the main if not the only way of growth and sustainable economic development for small islands. However, according to our proposal, on the contrary, these economies could be more exposed to and more impacted by such health crises through tourist flows than any other territories in the world. This finding cast doubts on the sustainability of tourism specialization in the medium and long run for small islands in a global context of recurrent health shocks, validating the "tourism-led vulnerability hypothesis" (Charles et al., 2019).

The rest of the paper is as follows. Section 2 presents a preliminary statistical investigation about the nexus between the prevalence of COVID-19 and international tourism attractiveness using a cross-country setting. Section 3 implements a cross-sectional multiple linear approach to check if the relationship remains valid when introducing several controlling variables. Section 4 discusses the main implications for small island economies. Section 5 concludes.

\footnotetext{
${ }^{3}$ All econometric simulations use XLSTAT and Eviews.

${ }^{4}$ The full list of the countries/territories is given in Table 11 in "Appendix". Small islands are identified in bold.
} 


\section{An exploratory statistical investigation}

\subsection{Description of our key variables: international tourism arrivals and COVID-19 prevalence}

Tourism attractiveness is measured by the number of international tourism arrivals in 2018 (the last available consolidated year) extracted from the WTO's database. Obviously, this annual indicator does not give a perfect view about the intensity of visitation during the first quarter of 2020 that is the period conditioning directly the spread of the infectious disease. However, it still reflects the potential average attractiveness of the country considered. ${ }^{5}$ The use of the year 2018 for tourism flows ensures that tourism arrivals are exogenous relative to the COVID-19 crisis, then allowing us to interpret the later estimated regressions as causal ones, i.e. the endogeneity bias does not exist. Moreover, following the last report of WTO (2020a), the time evolution of annual international tourism arrivals since 2009 is quite stable around a mean of about 4-5\%. All regional destinations are concerned by this stable positive trend until the breakdown in mid-March 2020 due to the lockdowns in many countries and the closing of many borders around the world. Accordingly, we argue that past tourism data (here 2018) are good predictors for tourism traffic relative to the period conductive to the spread of the COVID-19 that is October 2019 to March 2020. Note that in the context of infectious disease outbreaks, studying the role of outbound international tourists would have been also informative, but this data does not exist for numbers of small countries. Moreover, we opt to follow strictly the conventional definition of international tourism so that we do not consider cruise passengers.

COVID-19 prevalence for each country/territory is proxied by the number of cases up to April 32020 obtained from the database published on line by Johns Hopkins University. ${ }^{6}$ Most countries across the world experimented strict lockdowns since the third week of March. ${ }^{7}$ Considering a mean incubation period of 14 days, this early date secures our measurement of tourism arrivals from the influence of lockdowns. For several small island territories the data was obtained from local health institutions. We also take into account the size effect by dividing the original series by the number of population. In order to limit the problem of outliers, we applied the log transformation to the original series (in levels and per capita). Table 1 gives basic statistics for both original and modified variables. ${ }^{8}$

\footnotetext{
5 We do not have the means to take into account seasonality effects due to a lack of quarterly data. Then, we make the strong assumption of an equal distribution of the flows across the four quarters.

6 These data must be taken with caution due to a different strategy of domestic testing by each country. However the order of magnitude still stays informative.

7 WTO (2020b) indicates that 100\% of destinations were concerned by travel restrictions by April 2020.

8 Details about measurement, expected signs, time period, and sources are given in Table 12 in "Appendix".
} 


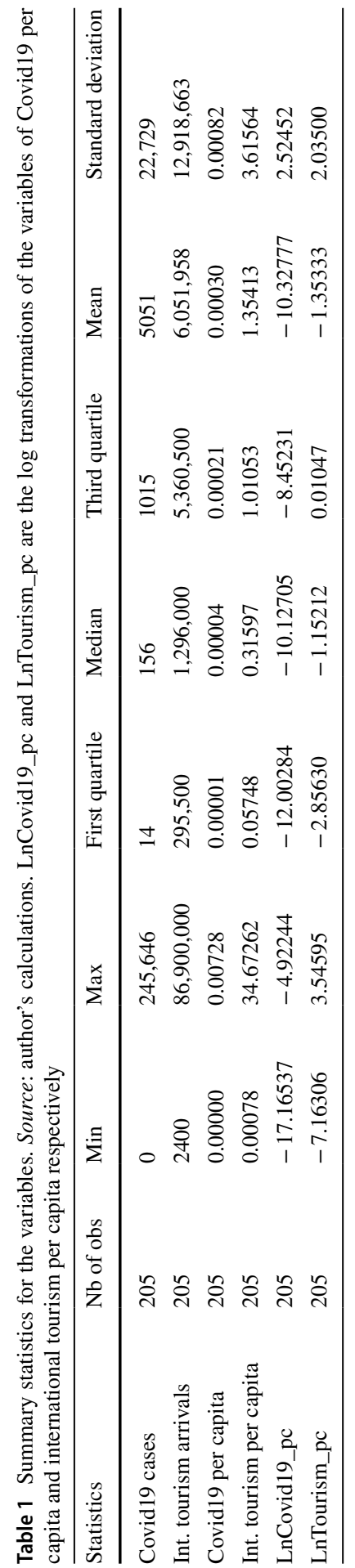




\subsection{Some striking stylized facts}

Before implementing preliminary econometric testing, simple interesting stylized facts about the nature of the relationship between COVID-19 infection outbreaks and inbound tourism flows must be discussed. Figures 1 and 2 put forward a strong matching between the highly infected areas (East Asia, Western Europe and USA) and the distribution of world transport networks. The apparent connection between the air transport network and the most affected regions is particularly striking but perfectly in line with the literature in medicine sciences. There is a consensus today about the impact of air travel on the spread of emerging and established infectious diseases (Smolinski et al., 2003; Mangili \& Gendreau, 2005; Leder \& Newman, 2005). Concerning the COVID-19, the potential ways for the dissemination consist in (1) of course the ability of a contagious human to travel to virtually any part of the world within only one or two days, (2) the travel process itself because of infections might be spread on the aircraft through close contact, large droplets and smallparticle aerosols, and (3) the time spent before boarding (the use of mass transportation to get to the airport and the close exposure to many people inside the often crowded terminals ${ }^{9}$ ).

Moreover, Table 2 points out that the countries the most concerned by the epidemic are also the countries the most attractive in terms of international tourism. Indeed, looking at the top-10 of the best performers relative to the variable of inbound tourism flows (Panel A), we find 8 of the 10 most infected economies that is USA, Spain, Italy, Germany, China, France, United Kingdom and Turkey. A similar conclusion can be formulated for the small island world (Panel B). 8 out of the 10 most affected small islands (Singapore, Hong Kong, Bahrain, Puerto Rico, Cyprus, Hawaii, Cuba, and Malta) belong to the 10 best insular performers in terms of international tourism arrivals. These first promising findings require of course a more robust investigation.

\subsection{A first simple econometric analysis over a worldwide cross-country sample}

Our main goal is to detect an empirical causal link between the prevalence of COVID-19 disease and international tourism attractiveness for a large worldwide sample including 205 countries/territories. Then, the hypothesis we want to validate is the more an economy characterized by high international tourism levels per capita the more this economy concerned with high levels of COVID-19 infections per capita. The empirical strategy is based on two steps: (1) testing for the correlation between COVID-19 infections per capita and international tourism arrivals per capita, and (2) estimating within a cross-section framework a causal linear regression of COVID-19 infections with inbound tourism flows as an explanatory variable. Note that the log transformation should strongly limit the influence of outliers. However, considering the fact that the 8 most affected countries by the COVID-19 represent

\footnotetext{
9 Wick and Irvine (1995) stated that the air inside the bus and airline terminal could have a higher level of microbial contamination than that inside the aircraft itself.
} 
together $77 \%$ of total cases, we ran the estimations also onto a reduced worldwide sample that is without USA, Spain, Italy, Germany, China, France, Iran and the United Kingdom. Moreover, in the extent that we focus specifically on the insular world, simulations are also implemented for a sample including only small islands.

On the one hand, we applied the usual procedures of Pearson and Spearman to test for the correlation between the number of COVID-19 infections per capita and inbound tourism flows per capita. Regardless of the sample, the correlation coefficients and the associated $p$ value (at the 1\% significance level) displayed in Table 3 indicate that a strong, positive and significant correlation holds between the two variables.

On the other hand, as already noted earlier, considering that the endogeneity bias is not expected to exist enables us to estimate the number of COVID-19 cases per capita (the dependant variable) as a linear function of international tourism arrivals per capita (the explanatory variable). The results are displayed in Fig. 3 and Table $4 .{ }^{10}$

First, surprisingly for a simple linear regression, the $\mathrm{R}^{2}$ is clearly strong. This indicates that 52.8\% for the Panel A, 55.2\% for the Panel B, and 58.2\% for the Panel $\mathrm{C}$, of the variability of the COVID-19 prevalence is explained by the international tourism attractiveness. ${ }^{11}$ Furthermore, the F-test of Fisher emphasizes that the variable of inbound tourism arrivals alone provides a significant proportion of information. The probability associated to the F-stat is lower than 0.0001, supporting that we cannot reject the null of a well-suited specification.

Second, looking at the estimated equations, a positive and significant trend characterises the nexus between COVID-19 infections per capita and annual inbound tourism arrivals per capita. Note that the intervals of confidence relative to both the constant and the coefficient of interest are very tight given some robustness to the estimates. Moreover, regardless the sample considered, the coefficient approximately equals 0.9 , underlining the presence of a quasi-proportional relation between the two variables. Insofar as these latter are used in logs, the estimated coefficient must be interpreted as an elasticity so that an increase of $10 \%$ in international tourism attractiveness results in an increase of around 9\% in the expected number of COVID-19 infections per capita. Accordingly, this preliminary study concludes that international tourism may be considered as both responsible for and victim of the outbreak of the COVID-19 crisis across the world.

\footnotetext{
${ }^{10}$ The robustness tests usually applied to check the statistical reliability of the specifications have been implemented with success. Indeed, the linear form is accepted (Harvey Reset test) together with the normality (tests of Shapiro-Wilks and Jarque-Bera) and the homogeneity (tests of Breusch-Pagan and White) of the residuals. The tests of Grubbs and Dixon have been used for detecting potential outliers. The results are available upon request.

${ }^{11}$ Of course, this result also indicates that taking into account additional determinants would improve significantly the explanatory power of the model. This will be done below.
} 




Fig. 1 Coronavirus COVID-19 cumulative cases in the world, April 3 2020. Source: the Center for Systems Science and Engineering (CSSE) at Johns Hopkins University

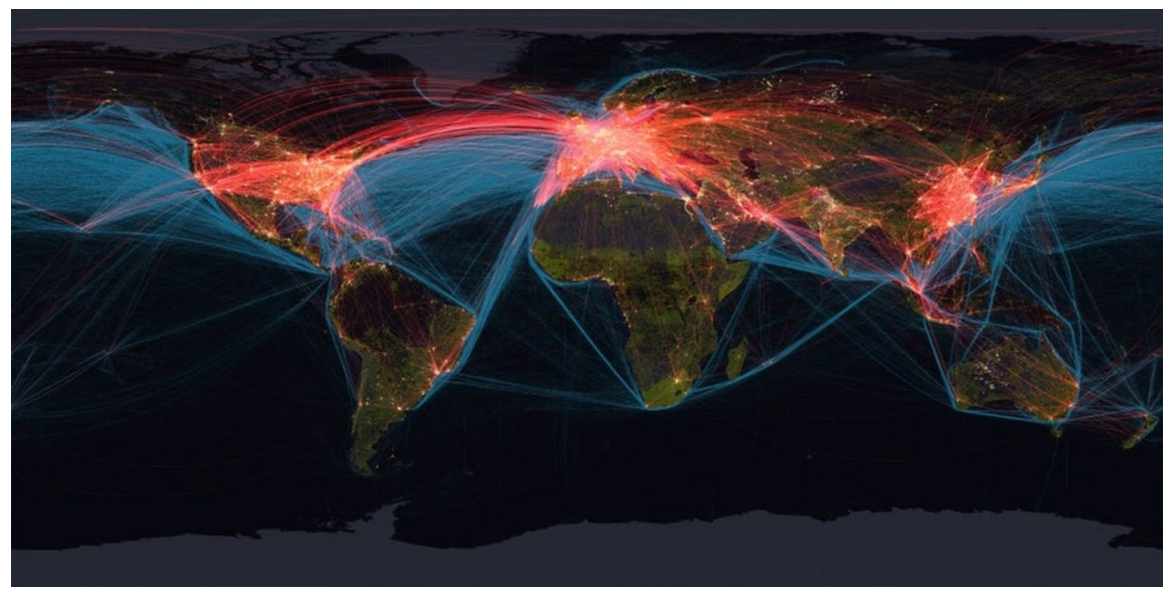

Fig. 2 Global transport networks (road, sea, air). Note: road transport in green, sea transport in blue, air transport in red. Source: AndrewGloe, December 62017 (colour figure online)

\section{A cross-sectional multiple approach for modelling the relationship between COVID-19 prevalence and international tourism attractiveness}

\subsection{The data and the rationale}

Even if the previous econometric analysis put forward a clear conditioning role for international tourism flows in the contagion process in the early stages of the pandemic, the specification suffers from a lack of robustness. Indeed, international 
Table 2 Top- 10 of the most concerned countries by COVID19 cases and international tourism arrivals. Source: The Center for Systems Science and Engineering (CSSE) at Johns Hopkins University; the WTO

\begin{tabular}{|c|c|c|c|}
\hline Countries & $\begin{array}{l}\text { Number of } \\
\text { COVID-19 } \\
\text { cases }\end{array}$ & Countries & $\begin{array}{l}\text { Inbound } \\
\text { tourism } \\
\text { arrivals }\end{array}$ \\
\hline \multicolumn{4}{|c|}{ Panel A: The Worldwide sample } \\
\hline USA & 245646 & France & $86,900,000$ \\
\hline Spain & 117710 & Spain & $82,000,000$ \\
\hline Italy & 115242 & USA & $75,600,000$ \\
\hline Germany & 85903 & China & $59,300,000$ \\
\hline China & 82509 & Italy & $52,400,000$ \\
\hline France & 59929 & Mexico & $39,300,000$ \\
\hline Iran & 53183 & United Kingdom & $37,700,000$ \\
\hline United Kingdom & 38659 & Turkey & $37,600,000$ \\
\hline Switzeland & 19303 & Germany & $37,500,000$ \\
\hline Turkey & 18135 & Thailland & $32,600,000$ \\
\hline \multicolumn{4}{|c|}{ Panel B: The small island world } \\
\hline Iceland & 1364 & Hong Kong & $29,263,000$ \\
\hline Singapore & 1114 & Macao & $18,493,000$ \\
\hline Hong Kong & 862 & Singapore & $12,051,000$ \\
\hline Bahrain & 672 & Bahrain & $11,621,000$ \\
\hline Puerto Rico & 378 & Hawaii & $9,760,000$ \\
\hline Cyprus & 356 & Puerto Rico & $3,542,000$ \\
\hline Reunion & 321 & Cuba & $3,491,000$ \\
\hline Hawaii & 319 & Cyprus & $3,187,000$ \\
\hline Cuba & 233 & Jamaica & $2,182,000$ \\
\hline Malta & 202 & Malta & $1,966,000$ \\
\hline
\end{tabular}

Table 3 Correlation tests between COVID-19 prevalence and International tourism arrivals. Source: Author's calculations. The tests are implemented at the $1 \%$ significance level

\begin{tabular}{|c|c|c|c|c|c|c|}
\hline \multirow[t]{2}{*}{ Variables } & \multicolumn{2}{|c|}{ The whole sample } & \multicolumn{2}{|c|}{ The reduced sample } & \multicolumn{2}{|c|}{ The small island sample } \\
\hline & Pearson & Spearman & Pearson & Spearman & Pearson & Spearman \\
\hline Coefficient & 0.728 & 0.741 & 0.743 & 0.762 & 0.768 & 0.697 \\
\hline$p$ value & $<0.0001$ & $<0.0001$ & $<0.0001$ & $<0.0001$ & $<0.0001$ & $<0.0001$ \\
\hline
\end{tabular}

tourism is not the only determinant of the spread of epidemics, and the bias of omitted variables casts doubts on the reliability of the results. Therefore, we estimate a multiple linear regression model by introducing several usual suspects suggested by the specialized literature in medicine sciences.

Smolinski et al. (2003) developed the most influencing approach in the field called "the convergence model". The authors show how the convergence of factors in four domains, that is (1) genetic and biological factors, (2) physical environmental factors, (3) ecological factors, and (4) social, political, and economic factors, 
Panel A. The whole sample

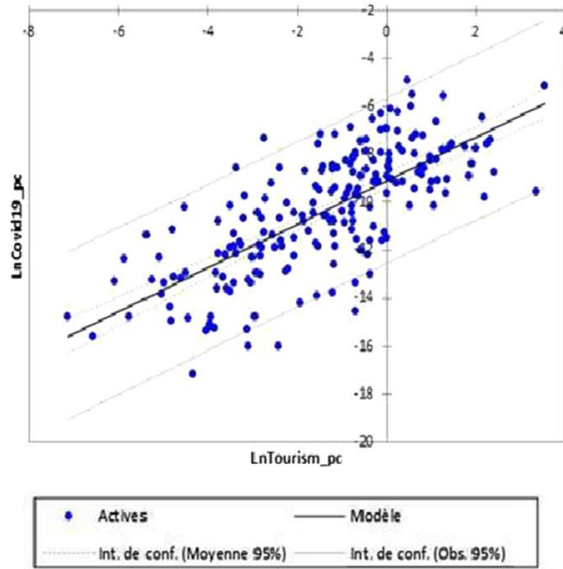

Panel B. The reduced sample

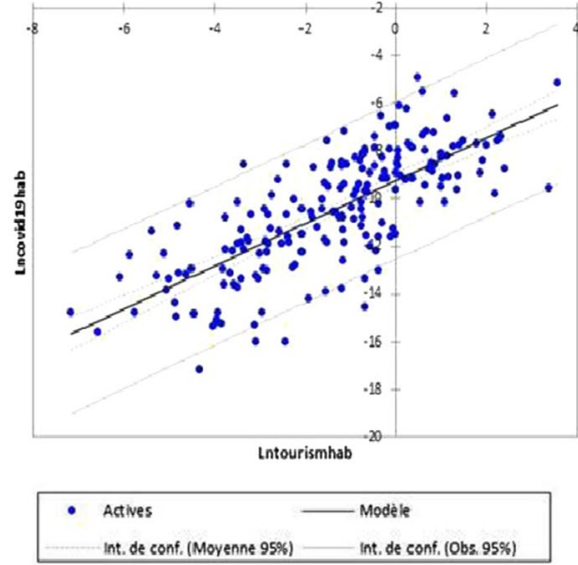

Panel C. The small islands sample

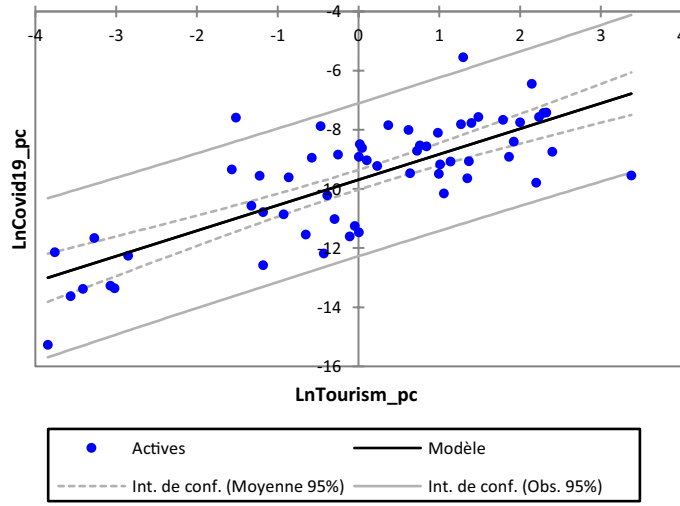

Fig. 3 Representation for the linear models. Source: author's calculations

impacts on the human-microbe interaction and results in infectious disease. Thirteen main factors, belonging to one or more of these four domains, were identified, namely (1) microbial adaptation and change, (2) human susceptibility to infections, (3) climate and weather, (4) changing ecosystems, (5) economic development and land use, (6) international travel and trade, (7) human demographics and behaviour, (8) technology and industry, (9) breakdown of public health measures, (10) poverty and social inequality, (11) war and famine, (12) lack of political will, and (13) intent to harm.

It is still too soon to have a clear idea about the biological characteristics of the virus, forcing us to not consider microbial adaptation and changing ecosystems. Moreover, considering the modes of transmission of this disease, that is direct contact or through air-borne transmission, we do not retain the factors of land use and technology/industry. Moreover, the most impacted regions at date are the most 


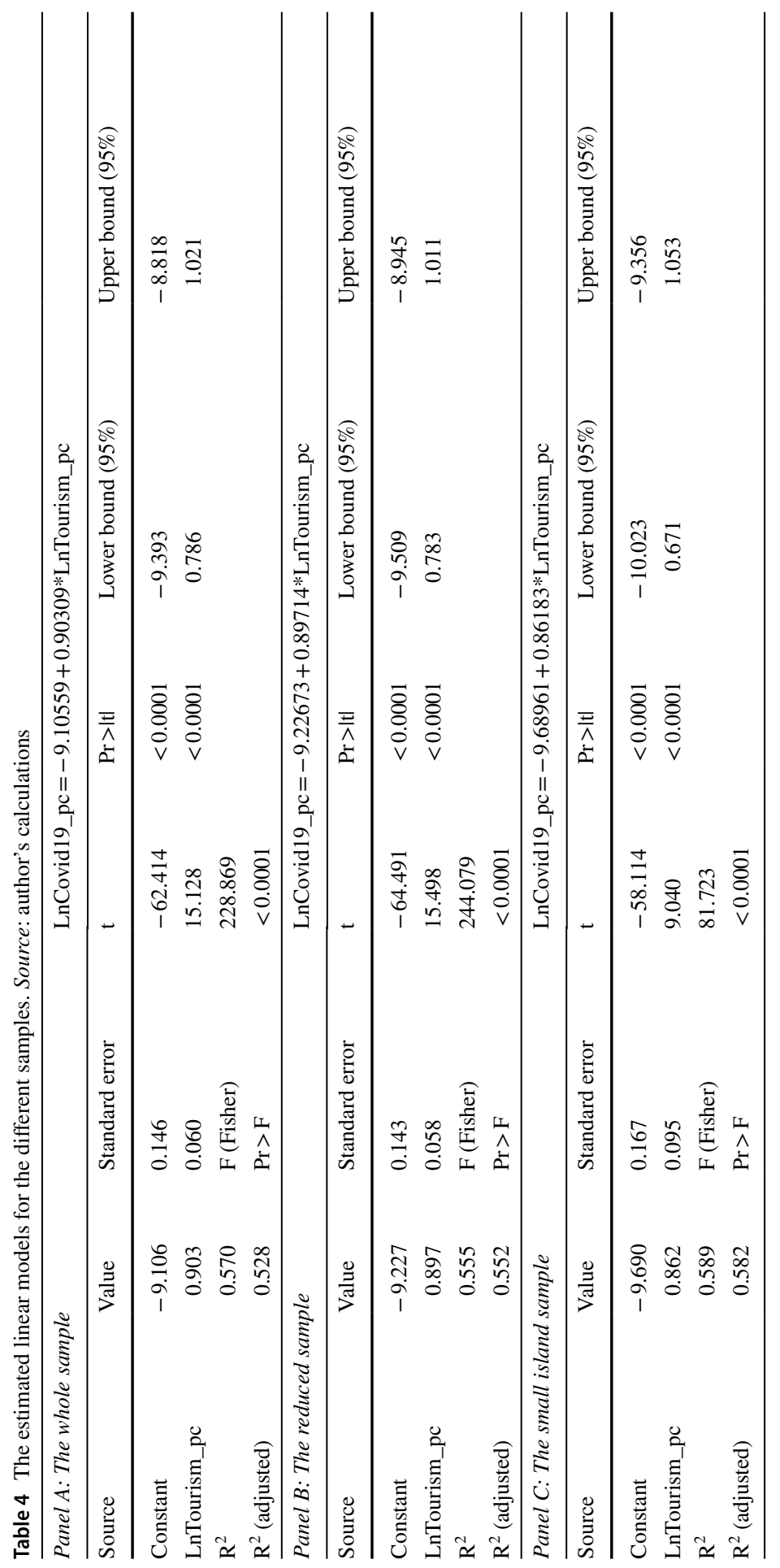


developed ones, then removing possible influences of poverty/inequality, ${ }^{12}$ war and famine, and intent to harm. Thus, in the empirical investigation, we finally focus on human susceptibility to infections, climate and weather, human demographics and behaviour, international travel and trade, breakdown of public health measures, and lack of political will. We present below the variables used and the rationale. ${ }^{13} \mathrm{We}$ do not discuss the factor "international travel and trade" because it correspond to our key variable, namely international tourism attractiveness, already presented in Sect. 2.

First, demographics and interactive behaviours increasing an individual's risk of exposure to a pathogen, or the increased probability of exchange of a contagious virus between humans, obviously boost the spread of an infectious disease. Consequently, demographic changes such as urbanization and the growth of megacities, the aging of the domestic population, and the growing number of individuals concerned by co-morbidity factors are likely to have a positive effect on COVID-19 cases in a country. Following this rationale, the proxies selected are population density [denspop], the urbanization rate [urbanpop], and the population aged 65 years and older in \% of the total population [65pop]. This latter variable could also reflect human susceptibility to infections because of the population ageing naturally alters the immune system.

Second, many infectious diseases are either strongly influenced by short-term weather conditions or display a seasonality indicating the possible influence of longer-term climatic changes. Climate can directly impact disease transmission through its effects on the replication and movement (perhaps evolution) of pathogens and vectors. Climate can also operate indirectly through its impacts on ecology and/or human behaviour. For the moment there is no scientific consensus about the role of climate on the replication and the survival probability of the SARSCov2. However, the fact that the vast majority of cases are concentrated in the temperate zones brings us to study the potential role of climate. Starting from the well-known climate classification of Köppen (see Fig. 5 in "Appendix"), ${ }^{14}$ we decide to adopt a less restrictive approach with only three different classes of climate: temperate, tropical and equatorial. To do that, three dummies, one for each climate, are introduced [hereafter, climattemp, climattrop and climatequa for the temperate, tropical and equatorial classes respectively]. Following Simmons (2015), temperate climates are generally defined as "environments with moderate rainfall spread across the year or portion of the year with sporadic drought, mild to warm summers and cool to cold

\footnotetext{
12 There is no macroeconomic evidence of any influence of poverty and inequality in the generating process of COVID-19 epidemic. But poverty and inequality are likely to be important factors on the microeconomic side. Within a population, the poorest individuals are also the most fragile and the most exposed to the disease. In addition, in wealthier contexts, the risk falls disproportionately on the shoulders of "essential" workers who have the modest wages. The occupations most resistant to remote working (construction, transportation, agriculture) are obviously working-classes.

13 Details about measurement, expected signs, time period, and sources are given in Table 12 in "Appendix".

14 Overall, the Köppen classification identifies five climate classes: A for tropical climates, B for dry climates, $\mathrm{C}$ for temperate climates, $\mathrm{D}$ for continental climates, and $\mathrm{E}$ for polar climates.
} 
winters". Therefore, our temperate climate dummy takes together the C and D types of Köppen. Moreover, we do not consider directly the B and E in the extent that they often correspond to sparsely populated regions. The countries associated with the B type are classified relative to its second dominant climate. Finally, within the A class, we disentangle the tropical type from the strict equatorial type. To assess the possible influence of mild temperature on COVID-19 cases, we use alternatively in the regression climattemp and climattrop/climatequa.

Third, breakdown or absence of public health measures and lack of political will are considered together. Indeed, these two factors belong to same reality of a bad preparation or complacency toward the threat of infectious diseases. We refer here to appropriate and quick reactions from all actors against the epidemics, governments of course but also corporations, officials, health professionals, and citizens. In this domain, the recent literature tends to oppose the East Asian model and the rest of the world including the western developed world (Duchâtel et al., 2020). No observer seems to contest today the exemplarity of East Asian countries in the fight against the COVID-19 disease. ${ }^{15}$ Accordingly, we add another dummy to control the specificity of the East Asian way of managing the COVID-19 crisis [hereafter, East Asia].

\subsection{Estimation and results}

To study the impact of international tourism on the COVID-19 epidemic, we use the traditional cross-section multiple linear regression so that:

$$
\text { LnCovid19_p } c_{i}=\alpha+\beta \text { LnTourism_p } c_{i}+\gamma X_{i}+\delta W_{i}+\varepsilon_{i} \quad \forall i=1, \ldots, N
$$

where the dependent variable is the prevalence of COVID-19 cases (per capita) and the key explanatory variable is international tourism attractiveness (per capita). $X$ is a vector of additional explanatory continuous variables (urban population, elderly population, population density), and $W$ encompasses all the dummies (climate, East Asian model). These latter allow us to control the robustness of the results about the effects of inbound tourism arrivals per capita.

Note that it is the first time that an empirical work in economics tries to identify econometrically the determinants of the COVID-19 epidemic which remains fundamentally a new infectious disease. Thus, we do not have any idea about an ideal for a well-suited specification. For this reason, we begin our analysis by using the most parsimonious specification, that is, by running our OLS regression excluding all other potential determinants of COVID-19 infections. Accordingly, our baseline model (Model (1) in Tables 6, 7, and 8) is the simple linear regression analysed in Sect. 2. Subsequently, several controls derived from the theory are included to assess

\footnotetext{
15 The East Asian toolbox includes (1) enforcement of individual quarantine with digital surveillance tools, rather than mass confinement, (2) early border controls to track imported infection at early stages of the crisis, also as an alternative to confinement, including with meticulous, sometimes intrusive, contact tracing, (3) the mobilization of industry in support of the national need for medical equipment, especially protective items like masks, and (4) social self-discipline and responsibility in times of epidemics.
} 


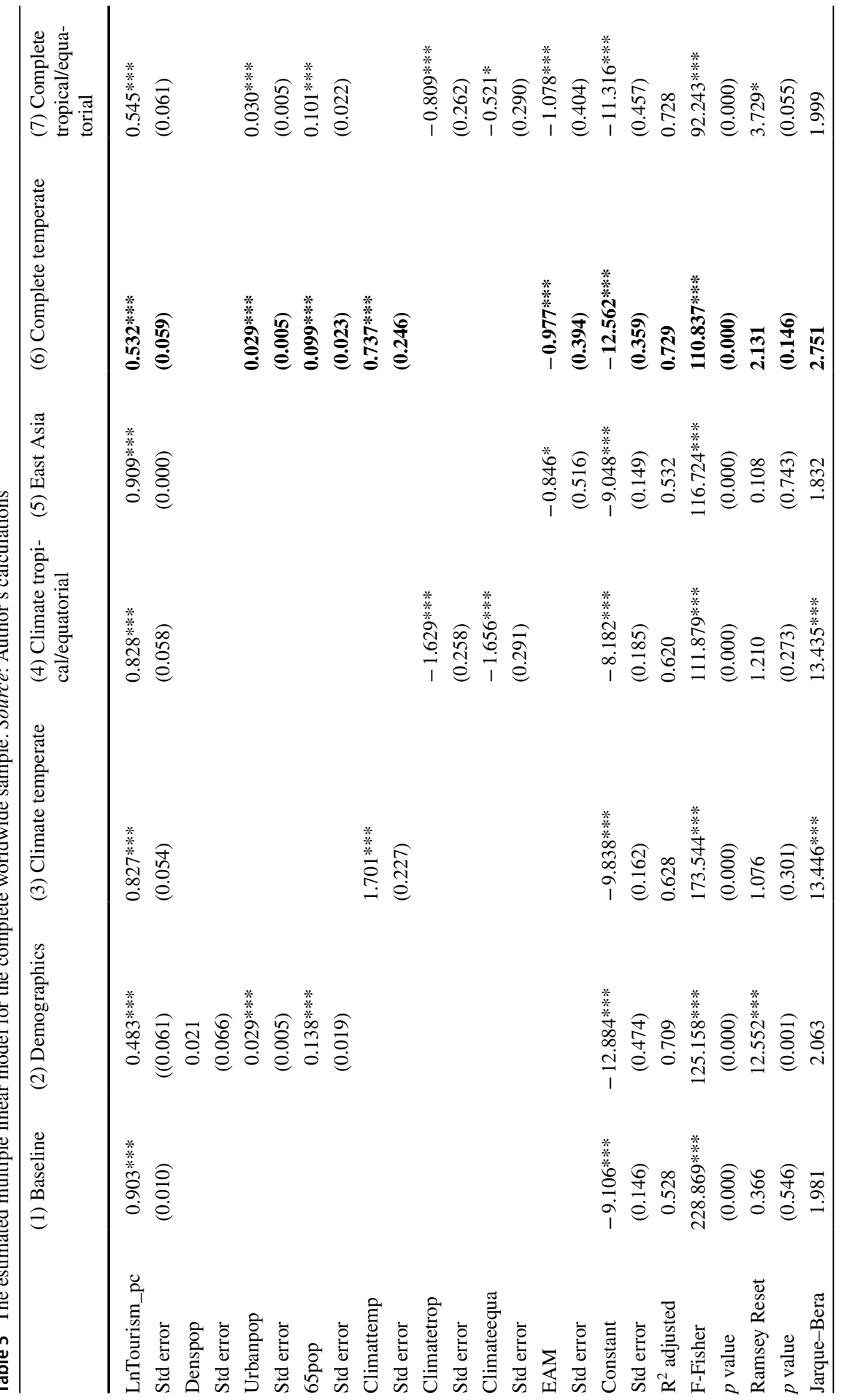




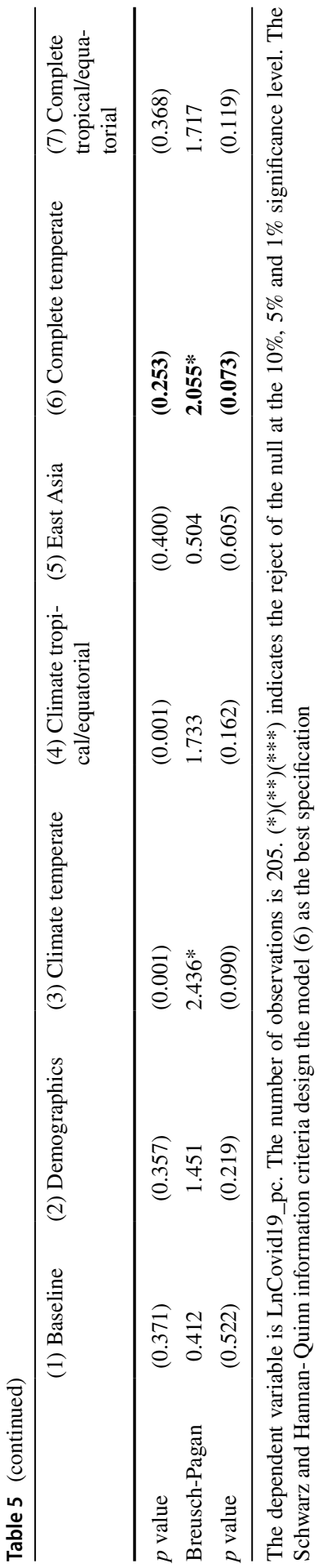




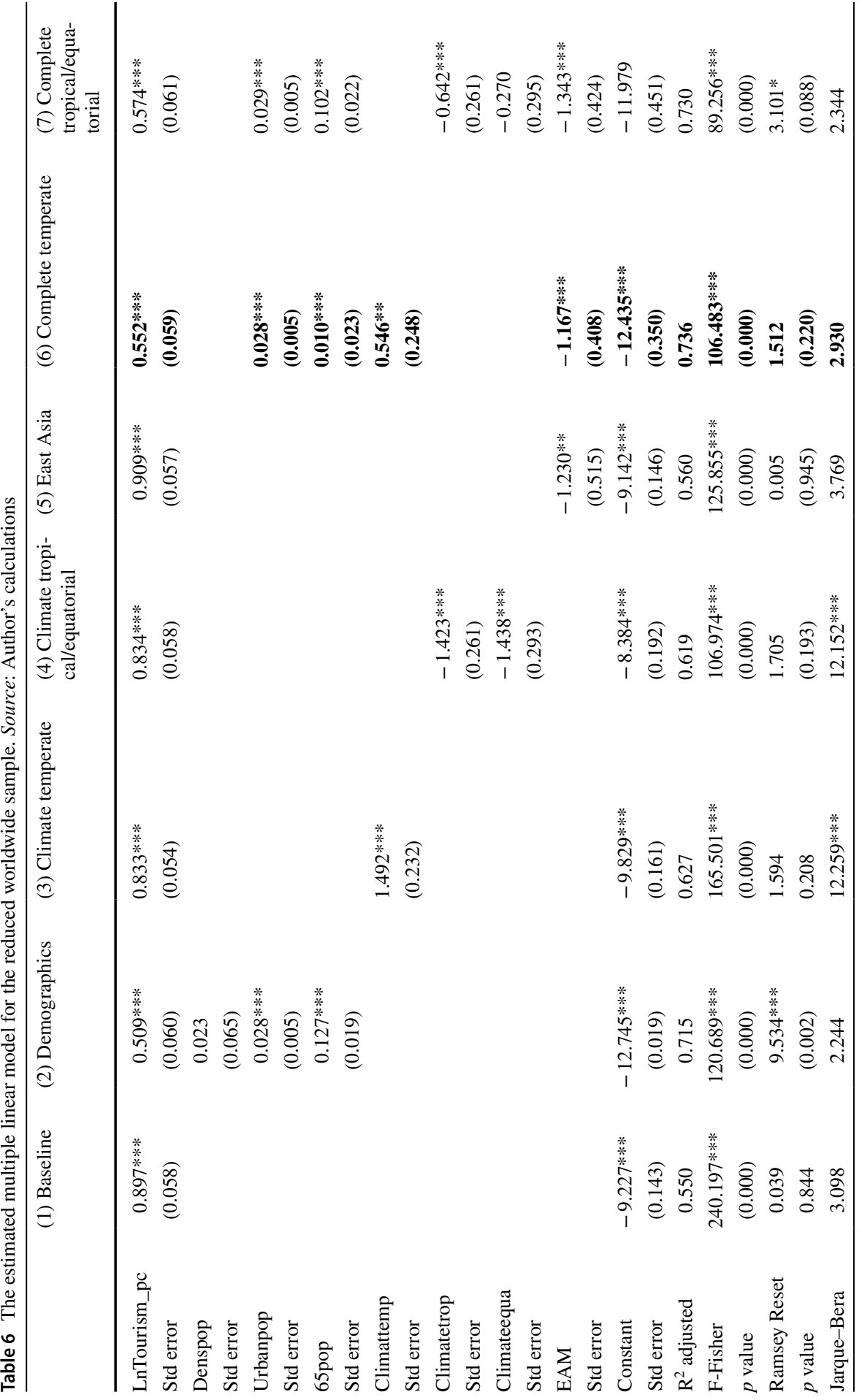




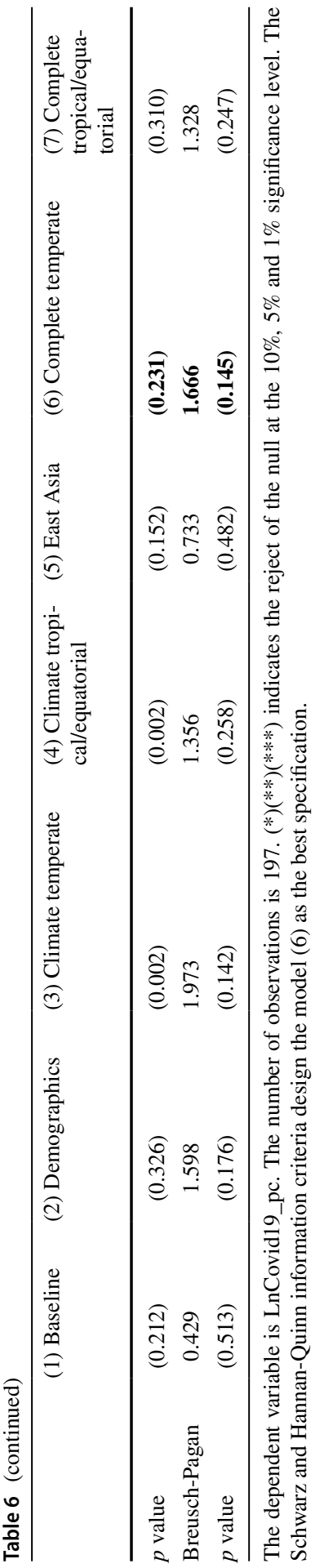




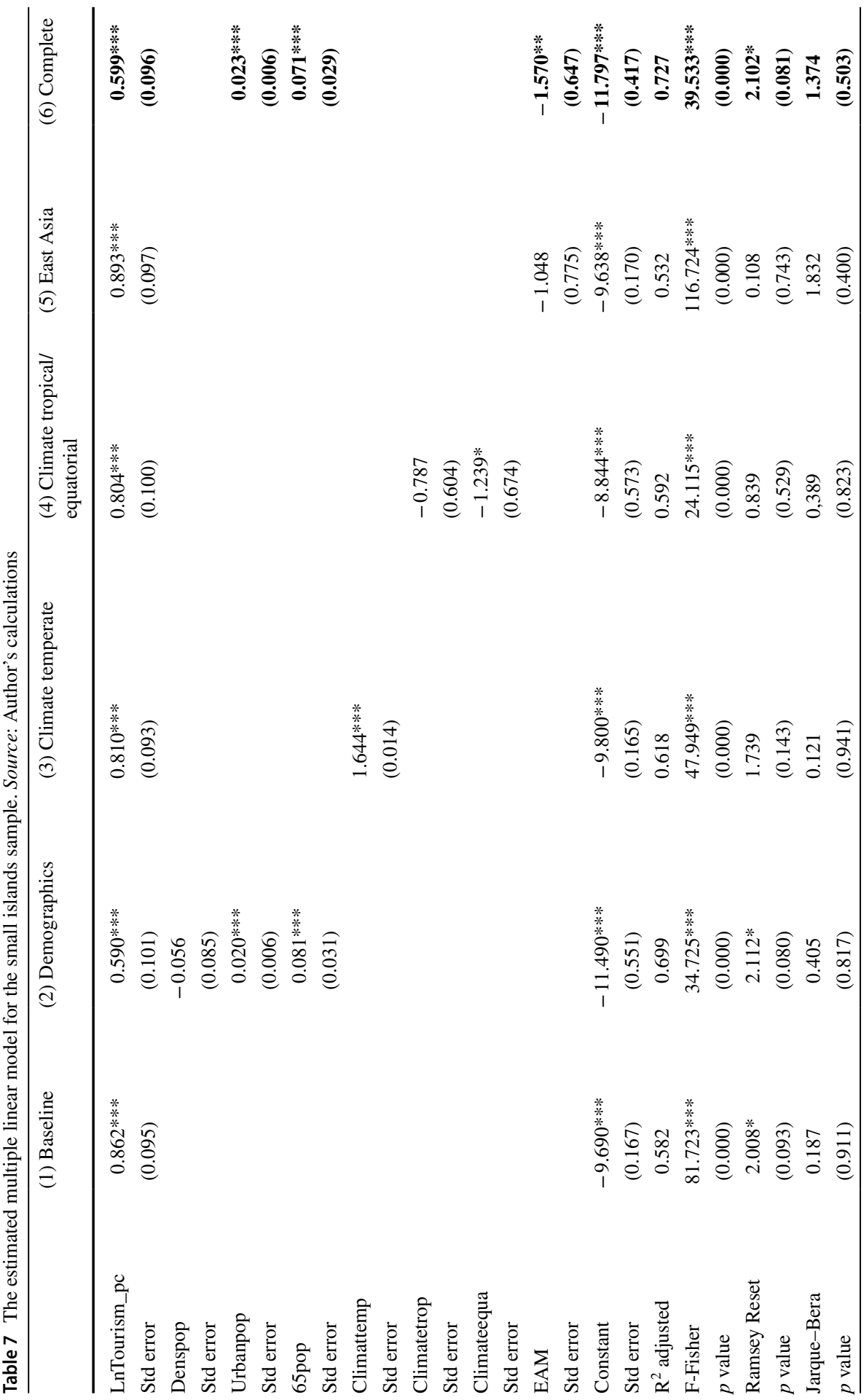




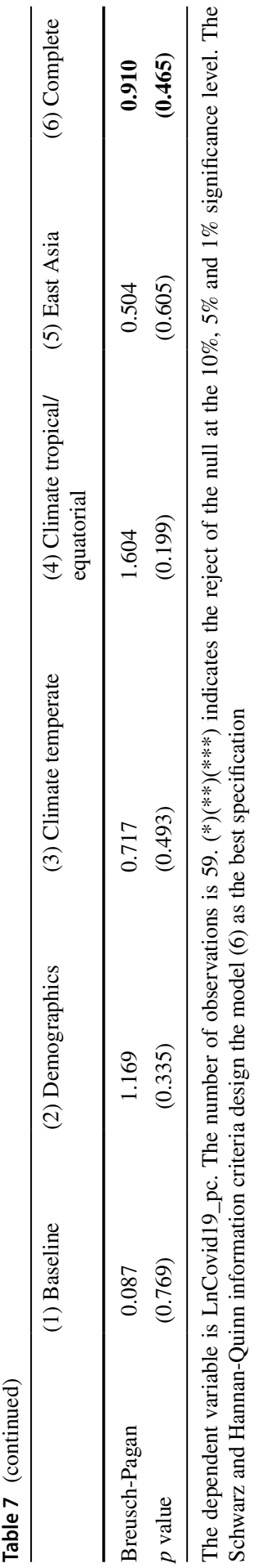


Table 8 International tourism indicators for a selected set of small island economies. Source: The World Development Indicators, The World Bank

\begin{tabular}{|c|c|c|c|}
\hline \multirow[t]{2}{*}{ Small island economies } & \multicolumn{3}{|l|}{ International tourism } \\
\hline & Per 1000 inhabitants & Receipts \% of GDP & $\begin{array}{l}\text { Receipts \% } \\
\text { of exports }\end{array}$ \\
\hline Turks and Caicos & $11,708.483$ & 76.982 & - \\
\hline Macao & $29,277.939$ & 73.266 & 88.730 \\
\hline Sint Maarten & 4378.413 & 71.539 & 58.871 \\
\hline Aruba & $10,222.495$ & 68.764 & 75.190 \\
\hline Antigua and Barbuda & 2793.760 & 60.289 & 84.311 \\
\hline Maldives & 2877.664 & 57.326 & 82.694 \\
\hline St. Lucia & 2171.654 & 51.461 & 81.271 \\
\hline Grenada & 1659.878 & 46.209 & 84.338 \\
\hline Palau & 5919.473 & 42.959 & 86.262 \\
\hline Seychelles & 3741.138 & 38.423 & 35.421 \\
\hline St. Kitts and Nevis & 2383.631 & 36.307 & 60.639 \\
\hline Vanuatu & 396.337 & 35.546 & 62.844 \\
\hline US Virgin Islands & 3561.513 & 31.180 & - \\
\hline St. Vincent and the Grenadines & 725.887 & 29.705 & 76.270 \\
\hline Bahamas & 4234.519 & 27.228 & 77.247 \\
\hline Cabo Verde & 1305.706 & 26.507 & 53.584 \\
\hline Belize & 1276.526 & 26.026 & 45.206 \\
\hline Fiji & 984.739 & 24.744 & 51.324 \\
\hline Samoa & 836.180 & 23.315 & 62.574 \\
\hline Barbuda & 2372.305 & 21.866 & - \\
\hline Dominica & 879.581 & 20.149 & 68.538 \\
\hline Jamaica & 842.631 & 19.721 & 53.376 \\
\hline Curacao & 2702.551 & 19.342 & 31.568 \\
\hline Guam & 9344.385 & 17.800 & - \\
\hline Sao Tome and Principe & 158.273 & 17.026 & 73.194 \\
\hline Cayman Islands & 7214.760 & 15.209 & 19.864 \\
\hline Mauritius & 1105.664 & 15.197 & 38.881 \\
\hline
\end{tabular}

the robustness of our results. Tables 5 and 6 display the results for the whole sample and the reduced sample respectively. Table 7 gives the findings for the small islands sample. We do not discuss the results given in Tables 6 and 7 as they are quite similar to those of Table 5. Indeed, the value and the signs of all coefficients are stable whatever the sample considered. The only striking difference is the non-significance of climate variables in the final specification (Model 6) for the small islands.

Let's begin with the model (2) which takes into account alongside our key variable the dimensions of demographics and human susceptibility to infections. Three main controls are used that is Denspop, Urbanpop and 65pop. All these factors have the expected signs but Denspop is clearly not significant statistically. All other things 
being equal, an increase of one unity in Urbanpop and 65pop leads to an increase in COVID-19 cases of about $2.9 \%$ and $13.8 \%$ respectively. ${ }^{16}$ Note that introducing the new variables does not change the significance and the sign of LnTourism but its estimated coefficient decreased notably from 0.903 to 0.483 . Moreover, this augmented model leads to a strong improvement in the $\mathrm{R}^{2}$ moving from 0.528 to 0.709 . This finding states the fundamental role of both international tourism and demographics for understanding epidemic dynamics.

Besides, the inclusion of the potential influence of climate in the specifications (3) and (4) does not change the main results concerning the impact of international tourism. Indeed, the coefficient of our key variable is significant and its value stays roughly the same. It should be noted that the model (3) gives the effect on the COVID-19 infections of living in a temperate region rather than in a hot region. The model (4) analyses the opposite that is the impact of living in a tropical or equatorial region rather than in temperate one. Whatever the specifications considered, a significantly high positive role of mild temperatures appears in the extent that living in a temperate climate increases the number of COVID-19 cases of about $170 \% .^{17}$ This finding is in accordance with the observation that almost all the Southern hemisphere is not strongly impacted by the infectious disease.

Another crucial determinant is the East Asian model. The model (5) points out that living in a East Asian country reduces drastically the number of COVID-19 infections of $84.6 \% .^{18}$ Consequently, our estimations seem to underline the effectiveness of the East Asian countries' responses to the epidemic. However, and more importantly, the international tourism parameter remains positive, stable, and highly significant.

Finally, the models (6) and (7) ran the regression with all the controls simultaneously. There is no notable difference between the two models even if the model (6) is the best one in terms of robustness. ${ }^{19}$ Indeed, the two models resist to the tests of global suitability, normality, heteroskedasticity, linearity, and multicollinearity at the 5\% significance level (see Table 13 in "Appendix"). However, the model (6) is associated with a stronger $\mathrm{R}^{2}$ and better performs according to the Schwarz and HannanQuinn information criteria. All the coefficients are significant and have the expected signs. Our key variable that is international tourism attractiveness remains an important factor of COVID-19 infections even if the value of the coefficient has reduced from 0.903 to 0.532 . We can conclude that an increase in inbound tourism arrivals per capita of $10 \%$ results in an increase in per capita COVID-19 cases of $5.32 \%$. In short, international tourism must be consider as a main factor of the COVID-19 outbreak, alongside with other important usual suspects derived from demographics, climate, and a strong public and private commitment in fighting against the disease.

\footnotetext{
16 These explanatory variables are in levels, then the estimates must be understood as the growth rate (multiplied by 100) of COVID-19 cases.

17 See the footnote 16 .

18 See the footnote 16 .

19 There is just one complete specification for the small islands sample due to the non-significance of climate variables. This is due probably to the fact that most small islands included in the sample are tropical ones.
} 


\section{Discussion and implications for the small island economies}

The findings resulting from this study are particularly relevant and crucial for small island territories. Undoubtedly, most of them are largely dependent on international tourism both in terms of GDP and of exports (see Table 8).

Mainstream literature often claims that tourism specialization is the best option for the small island world. Academics supporting the so-called "tourism-led growth hypothesis" argue that tourism specialization is the main if not the only way of sustainable economic development for small islands (Brau et al., 2011; Brida et al., 2016). Moreover, McElroy (2006) highlights that the "Small Island Tourist Economies" $[\mathrm{SITE}]^{20}$ display significant better macroeconomic performances than their "Migration, Remittances, Aid, and Bureaucracy" [MIRAB $]^{21}$ counterparts. Following the seminal work of Baldacchino and Milne (2000) about the "People, Resources, Overseas management, FInance, and Transport" [PROFIT] ${ }^{22}$ model, Bertram and Poirine (2007) support the previous results evidencing the spectacular effectiveness of the specific model based on high-quality tourism and offshore finance.

The favourable impact of tourism specialization makes a certain consensus in the short-run. However, its positive effect on the long-run is not so evident. Conversely, a recent strand of the literature in tourism economics promotes the "tourism-led vulnerability hypothesis" (Goavec and Hoarau, 2015; Charles et al., 2019). Tourism specialization is expected to make a country dramatically prone to adverse exogenous shocks resulting in high economic instability and structural vulnerability. Thereafter this structural vulnerability questions the sustainability of economic growth and development in the medium and long run (Guillaumont, 2010). The most influential approach (Butler, 2011), the so-called "Tourism Area Life Cycle [Hereafter, TALC], argues that all tourism destinations are characterized by a common dynamic process reproducing a S-shaped curve and experiencing a series of stages from exploration to involvement, development, consolidation, stagnation, and post-stagnation which can be a decline without convenient economic policies (see Fig. 4). In short, tourism development contains the seeds of its own destruction because beyond a certain threshold it damages the economic, social, cultural and ecological carrying capacity of the host territory. In addition, the transition from one stage to the next guided by chaos dynamics is not linear or deterministic (Russel and Faulkner, 2004; Russell, 2006). Tourism resorts, whatever its maturity, heavily

\footnotetext{
${ }^{20}$ The SITE model characterizes the small islands for which international tourism is the almost exclusive driving force of the economy.

${ }^{21}$ The MIRAB model, originally developed by Bertram and Watters (1985), describes a specific development model found in the insular world underlining the importance of migration, overseas remittances, foreign aid and public bureaucracy for the functioning of the local economy.

${ }^{22}$ The PROFIT model emphasizes the ability of certain small island jurisdictions to make strategic political decisions on their own, i.e. to manipulate larger nations to their advantage, in the global context which improve their economic welfare, for instance, act as tax havens, provide flags of convenience for shipping, obtain rents from their natural resources and benefit from the presence of military installations. Sometimes, these latter are associated with tourism, foreign aid and remittances.
} 
depend on a set of unpredictable triggers whose impacts are also unpredictable with a magnitude out of proportion to the initial shock. Amongst these triggers, the literature emphasized particularly the role of exogenous shocks, such as health crises. ${ }^{23}$ These one-off shocks are expected to damage the attractiveness of the destination sharply and instantly, but with the possibility of a persistent impact in accordance with the butterfly effect principle (Faulkner and Russel. 2001).

Our results are in line with this latter strand of literature. However, contrary to the previous works we question the exogenous property of health crises. We argue that international tourism development due to its globalized dimension strongly increases the probability of health epidemic outbreaks. In other words, the more a country attractive in terms of foreign tourism, the more this probability high, and the more it will be hurt by the necessary measures for limiting the spread of the disease such as air traffic restrictions and strict lockdowns. Thereafter, these healthcare measures are likely to generate a dramatic and deep economic and social crisis, especially for the countries largely depending on tourism such as numbers of small islands. Furthermore, the on-going climate change process, partly generated by the tourism industry (Lenzen et al., 2018), ${ }^{24}$ should magnify this phenomenon in the future. Humans can expect more such disease to emerge in the future, as climate change shifts habitats and brings wildlife, crops, livestock, and humans into contact with pathogens to which they have never been exposed (Hoberg \& Brooks, 2015).

The preliminary stylized facts about the economic situation of small islands at the end of 2020 seem to support the "tourism-led vulnerability hypothesis". Indeed, although small islands have been moderately hurt by the health consequences of the pandemic, ${ }^{25}$ empirical evidence states that they are among the most impacted territories by the induced economic crisis, and particularly the tourist-dependent ones. IMF (2020) claims that the GDP of small island economies, as a group, should collapse by a much higher $6.9 \%$ that is much more that the world score of $-6 \%$. OECD (2021) goes in the same direction showing that the contraction in small islands is likely to be larger than other groups of poor and vulnerable economies, such as LDCs $(-1.7 \%)$ and land-locked developing countries $(-2.5 \%)$. The same study argues that numbers of tourist-dependent small islands are expected to shrink by more than $16 \% .^{26}$

\footnotetext{
${ }^{23}$ Other exogenous shocks are also discussed, namely international economic and financial crises, wars, terrorism, and natural disasters (Baker \& Mc, 2005).

24 The tourism contribution to greenhouse gas emissions represents $8 \%$ of the total emissions over the recent period.

25 This relative success could be attributed to early public actions based on a mix of strict constraints on travelling before the arrival of the pandemic and regulations about social distancing once the disease has succeeded to enter the country (OECD, 2021).

26 Another problem must not be undervalued and could disturb the recovery process. Many small islands are confronted to tremendous public income losses due to the pandemic alongside more public spending for health emergency. The consequence is a strong increase in debt burdens resulting in depressing public investment and a limited ability to mitigate the adverse economic and social impacts of the COVID-19 crisis (OECD, 2021). Of course this indebtedness dynamic should be much more pronounced for the small islands depending on one or two key economic sectors as those specialized in tourism.
} 


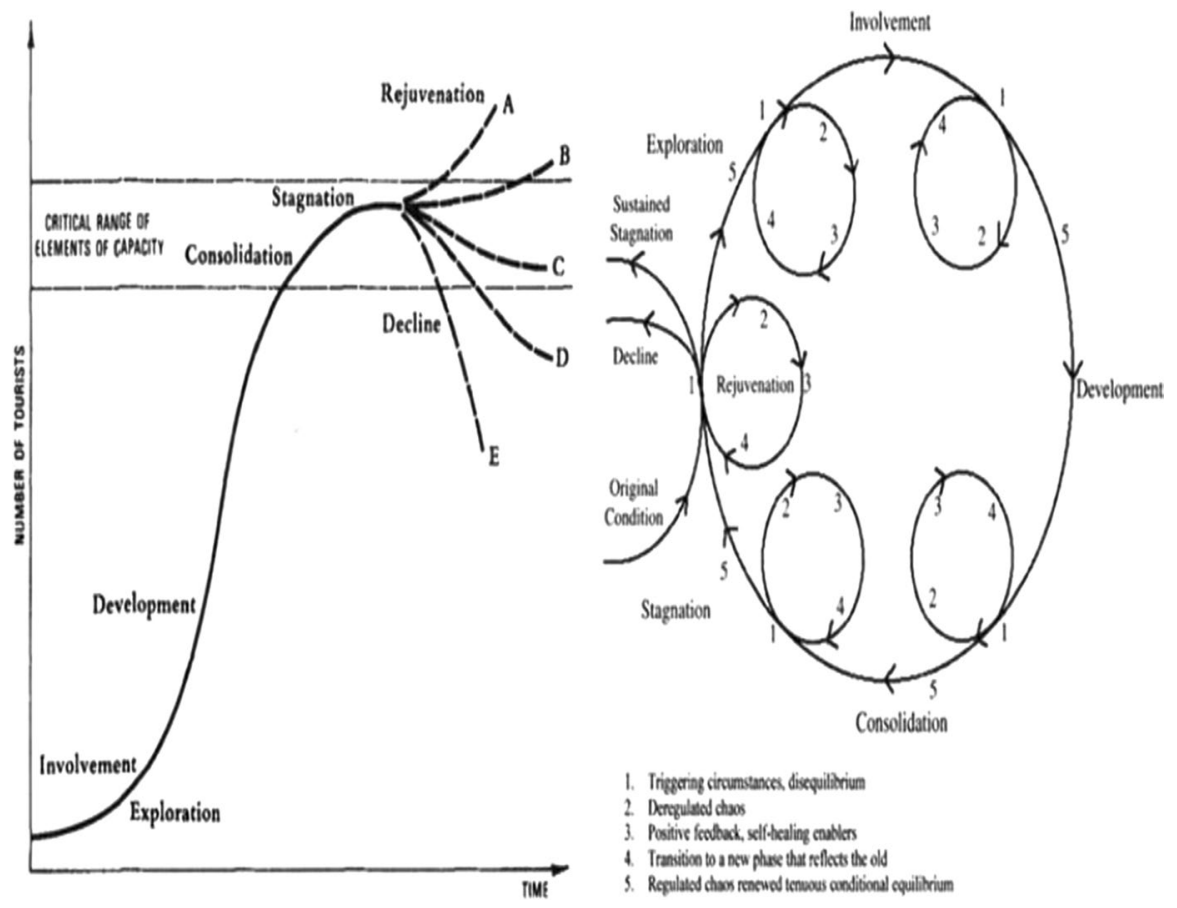

Fig. 4 The TALC model (standard and with chaos). Source: Charles et al. (2019)

In addition, a simple correlation analysis between economic growth in 2020 and the degree of tourism dependency (for the year 2018), based on the Pearson and Spearman tests applied to our sample (restricted to small islands), confirms these results. The correlation coefficients and the associated $p$ value (at the $1 \%$ significance level) displayed in Table 9 highlight the existence of a strong, negative, and significant correlation. Moreover, when we disentangle the sample in two groups according to the degree of tourism dependency, ${ }^{27}$ as in Table 10, a tremendous gap appears in terms of the severity of the economic crisis. The mean $(-16.027)$ and the median $(-14.826)$ for the group of the most tourism dependent territories are largely and significantly ${ }^{28}$ higher than the mean $(-2.874)$ and the median $(-4.652)$ for the group of the less tourism penetrated economies (Panels A and B in Table 10).

Of course, correlation is not causality, and all resulting policy recommendations should be taken with caution without a robust cost-benefit analysis. Nevertheless, we argue that, in the context of the insular world, tourism specialization is too much vulnerable to be considered as a sustainable strategy in the medium and long-run.

\footnotetext{
27 To determine the degree of tourism dependency, for commodity we select the variable "international tourism receipts as \% of GDP" and the threshold value of $15 \%$.

28 Using the non-parametric test of Wilcoxon allows us to reject the null of mean equality at the $5 \%$ significance level.
} 
This is due here to a very high exposure to health epidemics as the recent COVID19 one. Accordingly, we claim that relying on tourism is too dangerous for small islands, suggesting that policymakers should ideally opt for a strategy of a "relative diversification" rather than high tourism specialization ${ }^{29}$ when possible. Besides, the literature relative to the PROFIT model states that a degree of economic diversification is possible and works very well in the context of small islands. Even if the contribution of international tourism to GDP remains significant in almost all these economies, other main factors also drive the growth process as industry, offshore finance, public transfers, real estate sector, information and communication technology sector, geo-strategic rents, ... (Baldacchino \& Bertram, 2009). Note that this diversification option will be difficult if the international community does not accurately address the deteriorating debt situation in many small islands due to the health crisis. Numbers of small islands need help to find enough fiscal space for investments dedicated to a sustainable and resilient recovery. And as OECD (2021) recently said, more than the debt repayments suspension approach currently followed, the small island world "need a more comprehensive approach to debt, which could either take the form of debt relief initiatives or a Sovereign Debt Resolution Mechanism, a framework designed to provide a long-term solution to collective action and creditor co-ordination problems" (OECD, 2021, p. 19). ${ }^{30}$

However for the very small islands, global diversification may be at best inefficient, at worst impossible (Bertram \& Poirine, 2007). Another solution could result from building up a strong public-health system alongside a specialized tourism sector. Note that the very small size and the lack of economies of scale seriously limit the feasibility of this option without, once again, the assistance of the international community. Naturally, both bilateral and multilateral actors in the field of development assistance came to the rescue of small islands through in-king support, grant assistance, concessional lending and debt repayments (OECD, 2020), but most of the very small islands still crucially lack enough resources to face the crisis. ${ }^{31}$ Thus, we believe that the international community should design its financial aid policy towards very small islands considering a strategy based on three main priorities. First, promoting regional cooperation to build a robust regional health system with cost-sharing mechanisms is essential to face such another crisis in the future. Second, restarting the highly-impacted tourism sector is imperative but by enhancing its sustainability and resilience through integrating climate and sustainability requirements and standards in concessional lending and support recovery packages. Third,

\footnotetext{
${ }^{29}$ Earlier works already put forward this observation in the context of climate change for natural shocks such as cyclones, droughts or floods (Closset et al., 2018; Goujon \& Hoarau, 2020).

30 A discussion about the policy implications relative to the debt sustainability for small islands would be interesting but largely beyond the scope of this article. For more details, see OECD (2021).

31 Unfortunately, concerning the sovereign islands, this financial support was mainly concentrated on four economies with medium sized population (Dominican Republic, Haiti, Jamaica, and Papua New Guinea) that received $70.5 \%$ of the country-allocated financial support. Note that several economies (Kiribati, Timor-Leste, Tuvalu) have used sovereign wealth funds as fiscal buffer to counteract the fall in fiscal revenues due to COVID-19 crisis. In the future, the insular world would do well to follow these examples to address the potential instability of tourism revenues in hard times.
} 
Table 9 Correlation tests between economic growth in 2020 and tourism dependency for the group of small islands. Source: Author's calculations

\begin{tabular}{lll}
\hline Variables & Pearson & Spearman \\
\hline Coefficient & -0.692 & -0.747 \\
$p$ value & $<0.0001$ & $<0.0001$ \\
\hline
\end{tabular}

The tests are implemented at the $1 \%$ significance level

in spite of the population size constraint, economic diversification stays possible if focused on the so-called "blue economy". Indeed, very small islands are "quite big" ocean economies ${ }^{32}$ with vast untapped resources (fisheries, oil, gas, marine manufacturing and construction, offshore wind, tidal and wave energy, marine aquaculture, seabed mining for metals and minerals, marine biotechnology, ...) which can offer the most tangible alternatives to the traditional coastal and maritime tourism. Thus, international financial providers should help them to develop new ocean economy opportunities but of course with a special care about ecological and social sustainability.

\section{Conclusion}

Finally, this study showed that international tourism more than a victim appears mostly as a major factor of the COVID-19 pandemic outbreak. A positive and significant relationship exists, suggesting that an increase of $10 \%$ in inbound tourist arrivals per capita leads to an increase of 5.5\% in the prevalence of COVID19 infections after introducing several controls. This finding supports the well-accepted result in epidemiological and medicine studies that international travel and tourism constitute strong forces in the emergence of diseases and will continue to shape the outbreak, frequency, and spread of infections in geographic areas and populations (Baker \& Mc, 2005). However, note that using infection rate data from the early stages of the pandemic (the so-called first wave), as the present work has done, does not allow us to draw generalizations about long-term infection rates. Tourism economies are likely to show earlier spikes in infection than non-tourism economies. But once the virus is largely circulating inside the territory, and if no strict measures are taken, stopping inbound tourism flows will not stop the dynamics of the disease. Over time the inexorable epidemiological probabilities of infection are expected to distribute the infection burden across the world in line with the other driving forces (urbanization, the ageing of populations, seasonality, health conditions, strong social interactions ...).

This important conclusion is very disturbing for the small island economies. Most of them have adopted for a long time a model of development largely

\footnotetext{
${ }^{32}$ Small islands have limited land masses but a large ocean area which represents more than 2000 times the size of their land masses on average.
} 


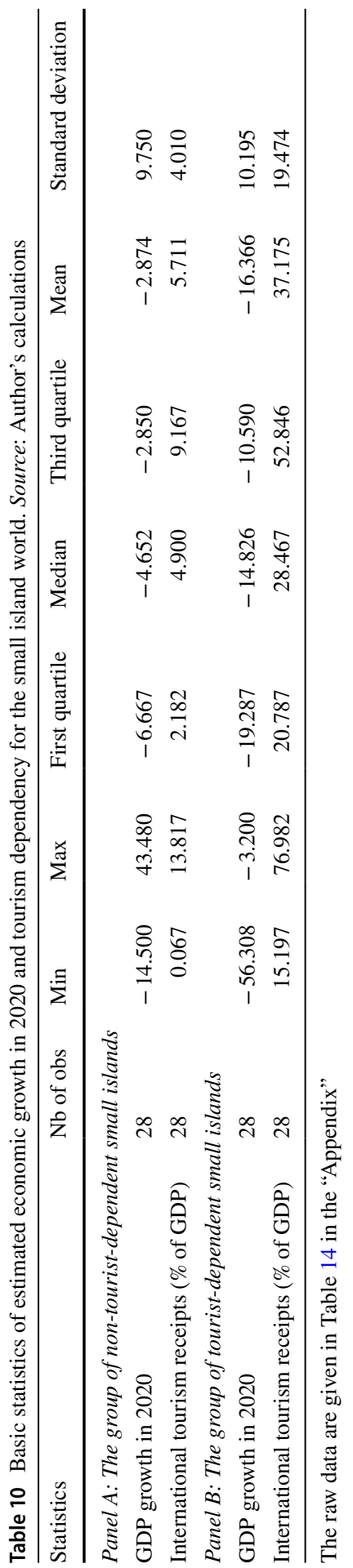


focused on international tourism. Taking into account the obvious impact of major extreme events such as health epidemics gives support to the "tourismled vulnerability hypothesis". We claim that, in a future world more and more struck by severe health crises, tourism specialization is too vulnerable to be considered as sustainable in the medium and long-run. Therefore, our conclusion is in accordance with the strand of the literature which argues that small island economies, and in particular small island tourist economies, are highly structurally vulnerable and require a special attention from the international community (Briguglio, 1995; Guillaumont, 2010; Closset et al., 2018). But more than public assistance, local policymakers in charge of the development strategy should reduce the domestic dependence on international tourism when possible. The quest of a "relative diversification" must become a priority. However, for the very small islands global diversification is just a "myth". In this case the priority should focus on the build-up of a strong public-health system alongside a specialized tourism sector. But even here, diversification is still possible if focused on the new ocean economy opportunities through the implementation of an innovative "blue recovery" strategy.

Note that this preliminary work needs additional investigations. In a future study, we will test for the validity of our proposal by introducing into the econometric specification other variables of control coming from medicine and climate sciences. It will be especially interesting to disaggregate our climate variable by taking into account more climate types. Moreover, including a dummy focusing on the countries with a well-known experience about hydroxychloroquine could be somewhat informative for the actual debate relative to an effective and not expensive treatment against the COVID-19 disease. Finally, and probably more crucial, one should test for the influence of all dimensions of international movements of people (outbound international tourism flows and migration) alongside inbound tourism flows.

\section{Appendix}

See Tables 11, 12, 13, 14 and Fig. 5. 
Table 11 The worldwide sample

\begin{tabular}{|c|c|c|c|c|}
\hline South Africa & Congo & Cayman Isl & Mexico & San Marino \\
\hline Albania & South Korea & Solomon Isl & Moldavia & $\begin{array}{l}\text { St Vincent \& the } \\
\text { Gren }\end{array}$ \\
\hline Algeria & Costa Rica & UK Virgin Isl & Monaco & Samoa \\
\hline Germany & Côte d'Ivoire & US Virgin Isl & Mongolia & $\begin{array}{l}\text { Sao Tome \& } \\
\text { Principe }\end{array}$ \\
\hline Andorra & Croatia & India & Montenegro & Senegal \\
\hline Angola & Cuba & Indonesia & Mozambique & Serbia \\
\hline $\begin{array}{l}\text { Antigua \& Bar- } \\
\text { buda }\end{array}$ & Curacao & Iraq & Myanmar & Seychelles \\
\hline Saudi Arabia & Danemark & Iran & Namibia & Sierra Leone \\
\hline Argentina & Djibouti & Ireland & Nepal & Sin Maarten \\
\hline Armenia & Dominica & Iceland & Nicaragua & Singapore \\
\hline Aruba & Egypt & Israel & Niger & Slovakia \\
\hline Australia & El Salvador & Italy & Nigeria & Slovenia \\
\hline Austria & Unit. Arab Emirates & Jamaica & Norway & Sudan \\
\hline Azerbaijan & Ecuador & Japan & New Caledonia & Sri Lanka \\
\hline Bahamas & Eritrea & Jordan & New Zeland & Sweden \\
\hline Bahrain & Spain & Kazakhstan & Oman & Switzerland \\
\hline Bangladesh & Estonia & Kenya & Uganda & Suriname \\
\hline Barbuda & Eswatini & Kiribati & Uzbekistan & Syria \\
\hline Belgium & USA & Kuwait & Pakistan & Tajikistan \\
\hline Belize & Ethiopia & Kyrgyzstan & Palau & Taiwan \\
\hline Benin & Fiji & Lao PDR & Panama & Tanzania \\
\hline Bermuda & Finland & Lesotho & Papua New Guinea & Chad \\
\hline Bhutan & France & Latvia & Paraguay & Czech Rep \\
\hline Belarus & Gabon & Lebanon & Netherlands & Thailand \\
\hline Bolivia & Gambia & Libya & Perou & Timor-Leste \\
\hline $\begin{array}{l}\text { Bosnia \& Herze- } \\
\text { govina }\end{array}$ & Georgia & Liechtenstein & Philippines & Togo \\
\hline Botswana & Ghana & Lithuania & Poland & Tonga \\
\hline Brazil & Greece & Luxembourg & French Polynesia & Trinitad \& Tobago \\
\hline Brunei & Grenada & Macao & Puerto Rico & Tunisia \\
\hline Bulgaria & Guadeloupe & North Macedonia & Portugal & Turkmenistan \\
\hline Burkina Faso & Guam & Madagascar & Qatar & Turks \& Caicos \\
\hline Burundi & Guatemala & Malaysia & Central African Rep & Turkey \\
\hline Cambodia & Guinea & Malawi & D.R. Congo & Tuvalu \\
\hline Cameroun & Guinea-Bissau & Maldives & Dominican Rep & Ukraine \\
\hline Canada & Guyana & Mali & Reunion & Uruguay \\
\hline Cabo Verde & French Guyana & Malta & Roumania & Vanuatu \\
\hline Chile & Haiti & Morocco & United Kingdom & Venezuela \\
\hline China & Hawaii & Martinique & Russia & Vietnam \\
\hline Cyprus & Honduras & Mauritius & Rwanda & Yemen \\
\hline Colombia & Hong Kong & Mauritania & St Lucia & Zambia \\
\hline Comoros & Hungary & Mayotte & Saint Kitts \& Nevis & Zimbabwe \\
\hline
\end{tabular}

Small island economies are in bold 


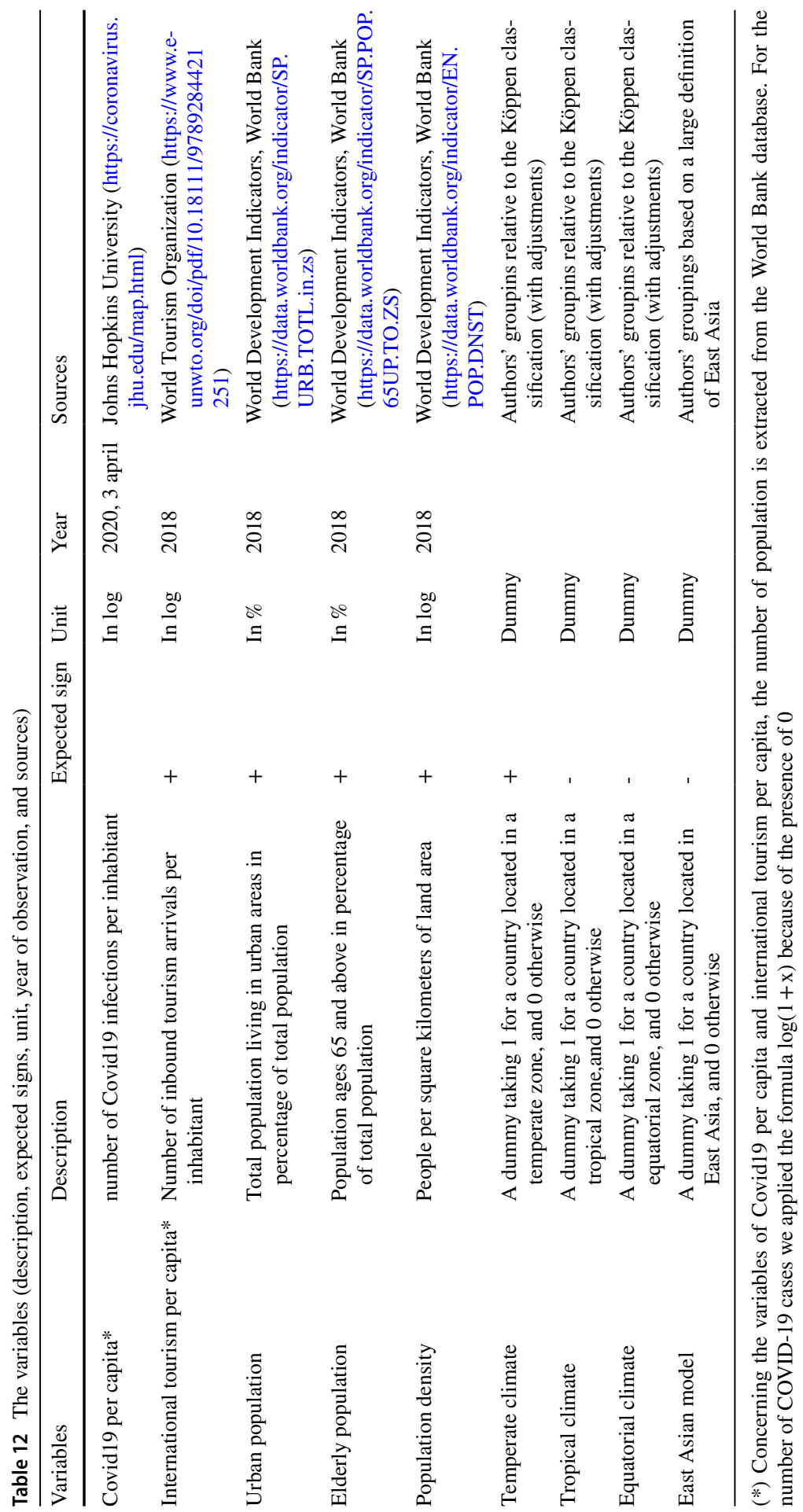


Table 13 Multicollinearity and the variance inflation factors (VIF). Source: Author's calculations Panel A: The whole sample

\begin{tabular}{|c|c|c|c|c|c|c|c|}
\hline Statistique & LnTourism_pc & \multicolumn{2}{|c|}{ Urbanpop } & EAM & 65 pop & LnDensity & Climattemp \\
\hline Tolerance & 0.571 & \multicolumn{2}{|l|}{0.704} & 0.947 & 0.379 & 0.810 & 0.560 \\
\hline VIF & 1.751 & \multicolumn{2}{|l|}{1.421} & 1.056 & 2.636 & 1.234 & 1.785 \\
\hline \multicolumn{8}{|c|}{ Climate $=$ Climattrop $/$ Climatequa } \\
\hline Statistique & LnTourism_pc & Urbanpop & EAM & 65 pop & LnDensity & Climattrop & Climatequa \\
\hline Tolerance & 0.529 & 0.695 & 0.893 & 0.386 & 0.803 & 0.525 & 0.458 \\
\hline VIF & 1.890 & 1.438 & 1.120 & 2.589 & 1.245 & 1.905 & 2.183 \\
\hline \multicolumn{8}{|c|}{ Panel B: The reduced sample } \\
\hline \multicolumn{8}{|c|}{ Climate $=$ Climattemp } \\
\hline Statistique & LnTourism_pc & \multicolumn{2}{|c|}{ Urbanpop } & EAM & 65 pop & LnDensity & Climattemp \\
\hline Tolerance & 0.572 & \multicolumn{2}{|l|}{0.710} & 0.941 & 0.393 & 0.813 & 0.579 \\
\hline VIF & 1.749 & \multicolumn{2}{|l|}{1.408} & 1.063 & 2.546 & 1.230 & 1.728 \\
\hline \multicolumn{8}{|c|}{ Climate $=$ Climattrop $/$ Climatequa } \\
\hline Statistique & LnTourism_pc & Urbanpop & EAM & 65 pop & LnDensity & Climattrop & Climatequa \\
\hline Tolerance & 0.527 & 0.701 & 0.876 & 0.400 & 0.806 & 0.522 & 0.445 \\
\hline VIF & 1.898 & 1.426 & 1.142 & 2.501 & 1.241 & 1.914 & 2.247 \\
\hline \multicolumn{8}{|c|}{ Panel C: The small islands sample } \\
\hline \multicolumn{8}{|c|}{ Climate $=$ Climattemp } \\
\hline Statistique & LnTourism_pc & \multicolumn{2}{|c|}{ Urbanpop } & EAM & 65pop & LnDensity & Climattemp \\
\hline Tolerance & 0.665 & \multicolumn{2}{|l|}{0.648} & 0.691 & 0.483 & 0.626 & 0.740 \\
\hline VIF & 1.502 & \multicolumn{2}{|l|}{1.543} & 1.448 & 2.070 & 1.597 & 1.352 \\
\hline \multicolumn{8}{|c|}{ Climate $=$ Climattrop $/$ Climatequa } \\
\hline Statistique & LnTourism_pc & Urbanpop & EAM & 65 pop & LnDensity & Climattrop & Climatequa \\
\hline Tolerance & 0.613 & 0.645 & 0.521 & 0.492 & 0.608 & 0.288 & 0.226 \\
\hline VIF & 1.632 & 1.551 & 1.919 & 2.034 & 1.646 & 3.468 & 4.432 \\
\hline
\end{tabular}




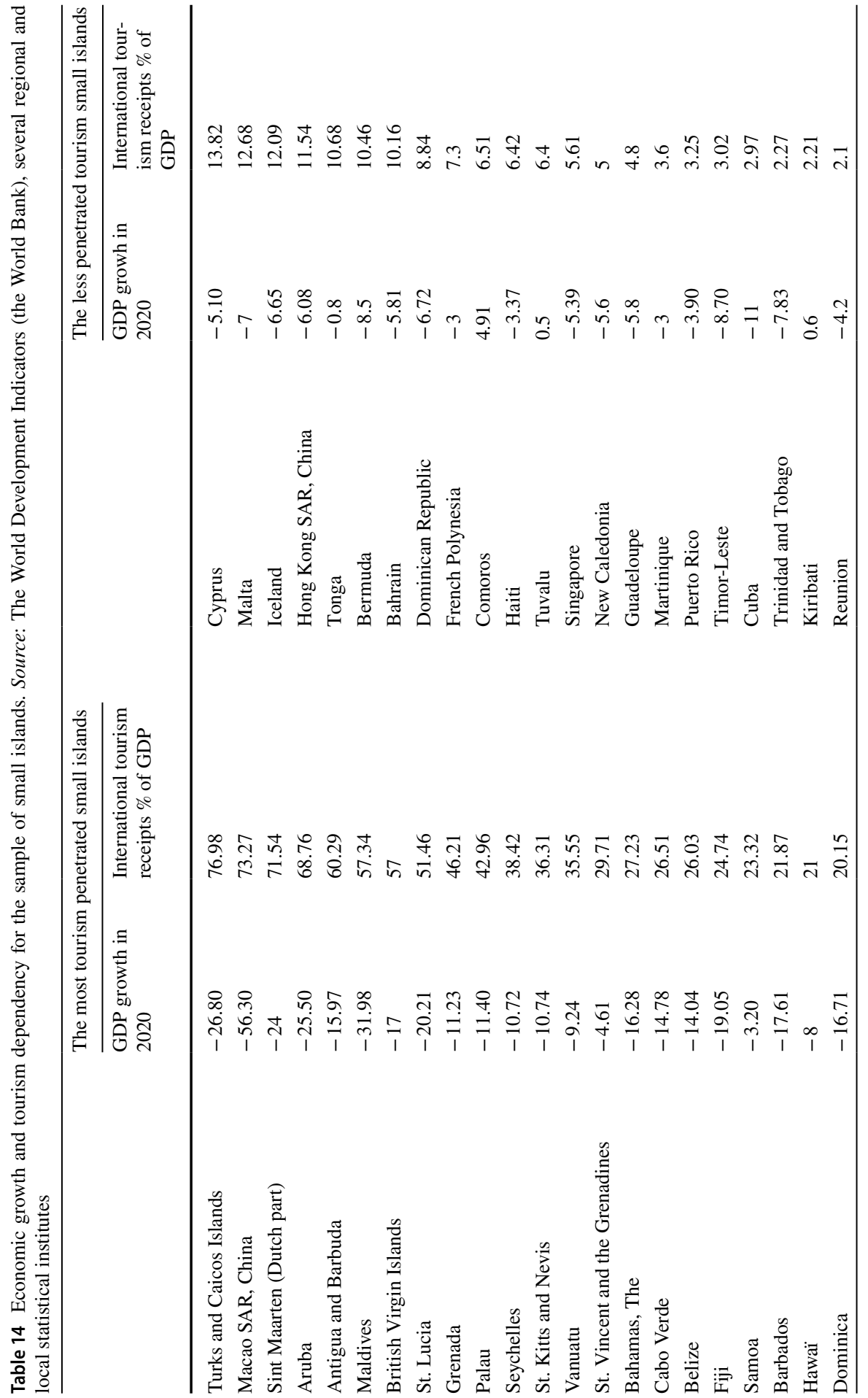




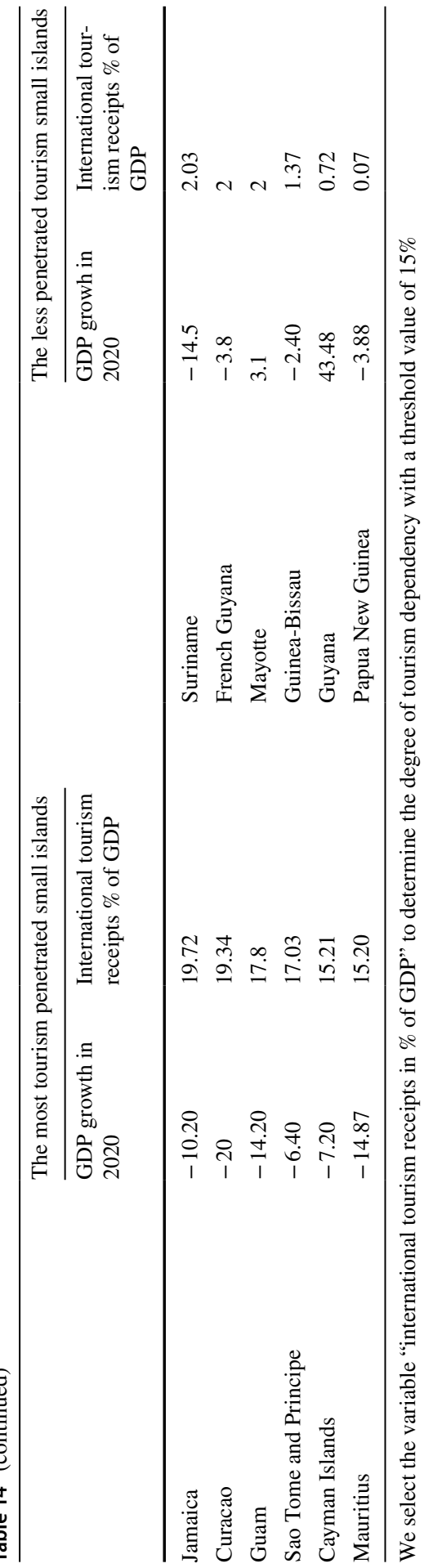




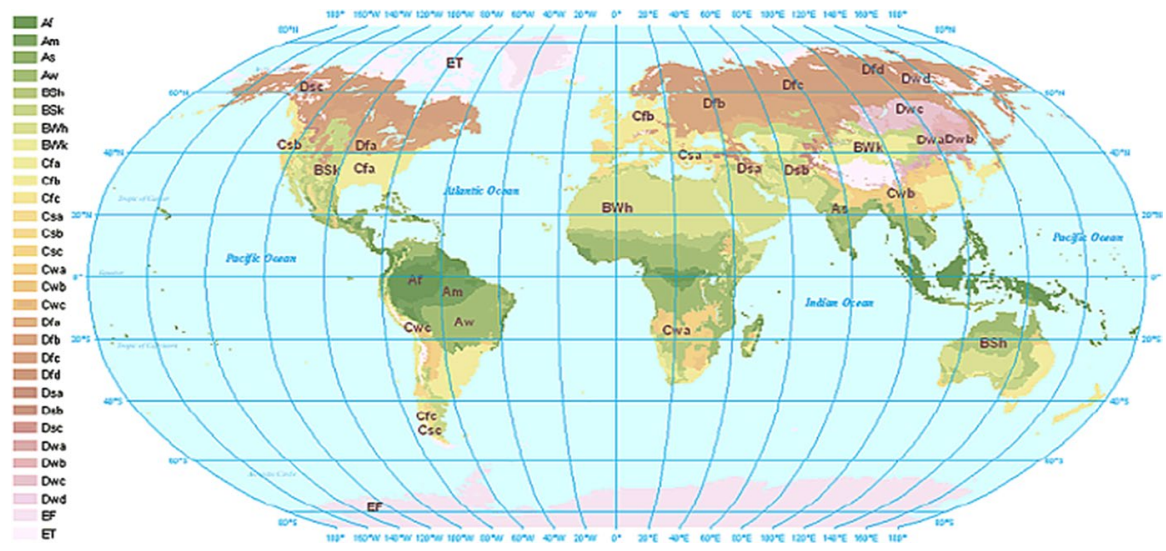

Fig. 5 World climate patterns according to Köppen. Source: Courtesy NOAA

\section{References}

Baker, D., \& Mc, A. (2005). Tourism and the health effects of infectious diseases: Are there potential risks for tourists? International Journal of Safety and Security in Tourism/hospitality, 12, 1-17.

Baldacchino, G., \& Bertram, G. (2009). The beak of the finch: Insights into the economic development of small economies. The round Table, 98(401), 141-160.

Baldacchino, G., \& Milne, D. (2000). Lessons from the political economy of small islands: The resourcefulness of jurisdiction. Macmillan.

Bertram, G., \& Poirine, B. (2007). Island political economy. In G. Baldacchino (Ed.), A world of islands: An island studies reader (pp. 332-378). Institute of Island Studies and Agenda Academic.

Bertram, G., \& Watters, R. F. (1985). The MIRAB economy in South Pacific microstates. Pacific Viewpoint, 26(3), 497-519.

Brau, R., Di Liberto, A., \& Pigliaru, F. (2011). Tourism and development: A recent phenomenon built on old (institutional) roots? The World Economy, 34(3), 444-472.

Brida, J. G., Cortes-Jimenez, I., \& Pulina, M. (2016). Has the tourism-led growth hypothesis been validated? A literature review. Current Issues in Tourism, 19, 394-430.

Brigulio, L. (1995). Small island developing states and their economic vulnerabilities. World Development, 23(9), 1615-1632.

Butler, R. W. (2011). Tourism area life cycle: Contemporary tourism reviews (pp. 1-33). Goodfellow Publishers.

Cannonier, C., \& Gallowey, B. M. (2018). The economic growth impact of tourism in small island developing states - Evidence from the Caribbean. Tourism Research, 25(1), 85-108.

Charles, A., Darne, O., \& Hoarau, J. F. (2019). How resilient is La Réunion in terms of international tourism attractiveness: An assessment from unit root tests with structural breaks from 1981-2015. Applied Economics, 51(24), 2639-2653.

Closset, M., Feindouno, S., Guillaumont, P., \& Simonet, C. (2018). A physical vulnerability to climate change index: which are the most vulnerable developing countries? Ferdi Working Paper, p 213.

Duchâtel M., Godement, F., \& Zhu V. (2020). Fighting COVID-19: East Asian responses to the pandemic. Policy Paper, Institut Montaigne. https://www.institutmontaigne.org/ressources/pdfs/publi cations/fighting-COVID-19-east-asian-responses.pdf

Faulkner, B., \& Russell, R. (2001). Turbulence, chaos, and complexity in tourism systems: A research direction for the New Millennium. In B. Faulkner, G. Moscardo, \& E. Laws (Eds.), Tourism and the 21st century: Reflections on experience (pp. 328-349). Continuum Books.

Goavec, C., \& Hoarau, J. F. (2015). Structural economic vulnerability and tourism dependence: New assessment for small island developing economies. Region and Development, 42, 157-188. 
Goujon, M., \& Hoarau J. F. (2020). Le tourisme insulaire à la merci du changement climatique: Une évaluation par un indice synthétique de vulnérabilité physique. Etudes et Documents, CERDI (forthcoming).

Guillaumont, P. (2010). Assessing the economic vulnerability of small island developing states and the least developed countries. Journal of Development Studies, 46(5), 828-854.

Hoberg, E. P., \& Brooks, D. R. (2015). Evolution in action: Climate change, biodiversity dynamics and emerging infectious disease. Philosophical Transaction of the Royal Society B: Biological Sciences, 370(1665), 20130553.

Hufnagel, L., Brockmann, D., \& Geisel, T. (2004). Forecast and control of epidemics in a globalized world. Proceedings National Academy of Sciences, 101(42), 15124-15129.

International Monetary Fund [IMF] (2020). World Economic Outlook database: October 2020. International Monetary Fund. https://www.imf.org/en/Publications/WEO/weo-database/2020/October/ download-entiredatabase

Leder, K., \& Newman, D. (2005). Respiratory infections during air travel. International Medicine Journal, 35, 50-55.

Lenzen, M., Sun, Y. Y., Faturay, F., Ting, Y. P., Geschke, A., \& Malik, A. (2018). The carbon footprint of global tourism. Nature Climate Change, 8(6), 522-528.

Mangili, A., \& Gendreau, M. A. (2005). Transmission of infectious diseases during commercial air travel. Lancet, 365, 989-996.

McElroy, J. L. (2006). Small island tourist economies across the life cycle. Asia Pacific Viewpoint, 47(1), 61-77.

Novelli, M., Gursing, B. L., Jones, A., \& Ritchie, B. W. (2018). No Ebola ... still doomed: The Ebolainduced tourism crisis. Annals of Tourism Research, 70, 76-87.

Organization for Economic Cooperation and Development (OECD) (2020). Evaluating the initial impact of COVID-19 containment measures on economic activity. OECD note. http://www.cica.net/wpcontent/uploads/2020/04/200331_OECD_evaluating-initial-impact-of-COVID-19.pdf.

OECD. (2020). COVID-19 survey-Main findings. Paris: OECD Publishing.

OECD (2021). COVID-19 pandemic: Towards a blue recovery in small island developing states. OECD Policy Responses to Coronavirus (COVID-19), 26 January. https://read.oecd-ilibrary.org/view/?ref= 1060_1060174-tnkmsj15ap\&title=COVID-19-pandemic-Towards-a-blue-recovery-in-small-islanddeveloping-states\&_ga=2.82227541.297058368.1628849432-2057211958.1628526027.

Peeri, N. C., Shrestha, N., Rahman, M. S., Zaki, R., Tan, Z., Bibi, S., et al. (2020). The SARS, MERS, and novel coronavirus (COVID-19) epidemics, the newest and biggest global health threats: What lessons have we learned? International Journal of Epidemiology. https://doi.org/10.1093/ije/dyaa0 33

Pratt, S. (2015). The economic impact of tourism in SIDS. Annals of Tourism Research, 52, 148-160.

Russell, R. (2006). Chaos theory and its applications to the tourism area life cycle model. In R. W. Butler (Ed.), The tourism area life cycle: Conceptual and theoretical issues (pp. 164-179). Channelview Publications.

Russell, R., \& Faulkner, B. (2004). Entrepreneurship, chaos, and the tourism area life cycle. Annals of Tourism Research, 31(3), 556-579.

Simmons, M. T. (2015). Climate and microclimates: Challenges for extensive green roof design in hot climates. In R. K. Sutton (Ed.), Green roof ecosystems, chapter 3 (pp. 63-80). Springer.

Siu, A., \& Wong, Y. C. R. (2004). Economic impact of SARS: The case of Hong Kong. Asian Economic Paper, 3(1), 62-83.

Smolinski, M. S., Hamburg, M. A., \& Lederberg, J. (2003). Microbial threats to health: Emergence, detection, and response. Committee on emerging microbial threats to health in the 21 st century. http://www.nap.edu/catalog/10636.html

Wick, R. L., Jr., \& Irvine, L. A. (1995). The microbiological composition of airliner cabin air. Aviation, Space and Environmental Medicine, 66(3), 220-224.

World Tourism Organization (WTO) (2020b). New data shows impact of COVID-19 on tourism as UNWTO calls for responsible restart of the sector, News Release, 22 June, Madrid. https://www. unwto.org/news/new-data-shows-impact-of-covid-19-on-tourism

World Health Organization (WHO) (2020a). Coronavirus disease (COVID-2019) situation reports. https://www.who.int/emergencies/diseases/novel-coronavirus-2019/situation-reports/

World Tourism Organization (WTO) (2020a). World tourism barometer, 18(1), January, 1-5. https:// webunwto.s3.eu-west-1.amazonaws.com/s3fs-public/2020-01/UNWTO_Barom20_01_January_ excerpt.pdf 
Yang, Y., Zhang, H., \& Chen, X. (2020). Coronavirus pandemic and tourism: Dynamic stochastic general equilibrium modelling of infection disease outbreak. Annals of Tourism Research (forthcoming).

Publisher's Note Springer Nature remains neutral with regard to jurisdictional claims in published maps and institutional affiliations. 